\title{
Дихотомија поимања вриједности у библијском контексту Млетачког трговца
}

\author{
Младен Р. Радуловић* \\ Висока пословно-техничка школа Добој
}

Кључне ријечи:

Библија

хришћани

Јевреји

Антонио

Шајлок

зеленаштво

богатство

љубав

правда

милосрђе

\section{Апстракт}

У овом раду ћемо се бавити начином на који су Шекспирове библијске алузије у Млетачком трговиу кориштене у њиховом драмском контексту фокусирајући се на библијске алузије као структурално интегришуће елементе драме. Покушаћемо да покажемо колико је Шекспирово познавање Библије дјеловало као центрипетална сила у служби његове умјетности и постизања дубљег значења у Млетачком трговиу, умјесто као центрифугална сила која је усмјерена на дубља значења изван саме драме гдје сви путеви воде у Рим, тачније, ка алегоријама Светог писма. Настојаћемо да илуструјемо на примјеру Млетачког трговиа како је Шекспир користио мноштво домишљатих начина да би продубио и проширио учинковитост карактеризације ликова, дијалога, индиција, иронија којима је сваку тему унутар драме разрадио до најситнијих детаља прилагодивши је библијским сазнањима која је елизабетанска публика у то вријеме сигурно морала имати, јер је присуство на богослужењима сваке недјеље и поводом највећих празника током године било законом прописана обавеза сваког поданика тадашњег врховног поглавара Англиканске цркве, Елизабете I. У ужем смислу, овај рад има за циљ да објасни како поједине библијске алузије у Млетачком трговиу обављају функцију интегришућих елемената драме и како се кроз њихову призму може посматрати мноштво тема и мотива као саставних и неодвојивих дијелова драме, у нашем случају, Шајлокова употреба Библије и мотив давања новца у зајам. У ширем смислу, требало би да открије како ове библијске алузије доприносе слојевитости драме кроз коју се објелодању вриједности својствене елизабетанској публици по питању наведене теме и мотива у Млетачком трговиу. (примюено: 17. августа 2021; прихваћено: 24. септембра 2021) www.anali.fil.bg.ac.rs

АНАЛИ ФИЛОЛОШКОГ ФАКУЛТЕТА

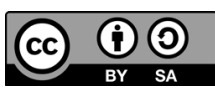

* Висока пословно-техничка школа Добој Озренских српских бригада 6р. 5A Добој, Република Српска mladendana@yahoo.com 


\section{1. Увод}

Иако је реално претпоставити да је Вилијам Шекспир (енгл. William Shakespeare; Стратфорд на Ејвону, кршт. 26. април 1564. - Стратфорд на Ејвону, 23. април 1616.) био врло добро упознат са званичном политиком Англиканске цркве и Законом о јединствености заједничке молитве (Act for the Uniformity of Common Prayer) краља Едварда VI из 1549. године, којом се забрањује свака појединачна литургијска пракса по бискупијама и надбискупијама и употреба „свих осталих богослужбених књига које се разликују од Молитвослова (The Book of Common Prayer)"1 (Gee/Hardy, 1914: 358), не можемо се отети утиску да је Шекспир у великој мјери црпио инспирацију и из римокатоличке литургијске праксе која је, упркос снажном притиску пуританског покрета међу свештенством Цркве Енглеске (Church of England), успјевала да се одржи испод површине религиозног живота у доба краљице Елизабете І. Наиме, велики број бискупа и свештеника је наставио да у тајности служи мису, према обреду Римокатоличке цркве, о чему пише и Алфред Полард (Alfred Pollard) у дјелу Историја Енглеске (The History of England from the accession of Edward VI to the death of Elizabeth (1547-1603)) у коме наводи „да би често управо онај исти свештеник који је обављао англиканско богослужење у јавности да би задовољио закон, затим у тајности служио (римокатоличку) мису да би умирио своју савјест"2 (Pollard, 1923: 280). Упркос неповољним околностима током периода Енглеске реформације, римокатолички обред је и даље остао доступан за све оне који су истрајавали на осјећању припадности римокатоличанству. Самим тим, постоји велика вјероватноћа да је Шекспир имао прилику да се подробније упозна са римокатоличком литургијском праксом током путовања са глумачком дружином.

Осим могућности да су присуство тајним римокатоличким литургијским обредима и разговори са свештеницима који су се упорно држали традиционалне богослужбене праксе у одређеној мјери надахнули Шекспирово стваралаштво, постоје докази да је у кругу Шекспирове породице и његових познаника било католичких рекузаната. Већина њих је у страху од прогона вјешто крила литургијске католичке књиге или их чак спаљивала на први знак да ће бити ухваћени, па постоји велика могућност да је Шекспир преко људи из свог ближег окружења долазио у посјед римокатоличких богослужбених књига које су му послужиле као инспирација. У сваком случају, уколико већ не постоје апсолутно поуздани спољни докази доступности библијских извора које је Шекспир у виду алузија уградио у само ткиво Млетачког трговиа (The Merchant of Venice, 1595), учинивши их неодвојивим и интегришућим елементима саме драме, онда они непорециво постоје у самом тексту.

Шекспир често посеже за библијским алузијама у свом стваралаштву у намјери да га учини пријемчивијим за публику којој су ријечи Светог писма

1 Енг."...all other books of service differing from the Prayer Book”. Сви преводи цитата у даљем раду, осим превода стихова из Шекспировог комада, дјело су аутора овог рада.

2 Енг. "Often the same priest read the Anglican service in public to satisfy the law and then said Mass in secret to satisfy his conscience". 
дио богослужбене свакодневице. У неким Шекспировим дјелима, библијске алузије имају мање проминентну улогу, док у другима, као што је то случај у Млетачком трговиу, оне представљају неизоставне елементе од суштинске структуралне и семантичке важности. У Млетачком трговиу, библијске алузије су савршено послужиле Шекспиру у сврху отварања комплексних питања поимања морала, правде и милосрђа. Служећи се библијским алузијама, Шекспир вјешто припрема публику на могуће сукобе интерпретација при давању одговора на ова замршена питања. Једним таквим сукобом интерпретација, односно, начином на који Шајлок и хришћани Венеције схватају и користе ријечи Библије, позабавићемо се у наредним поглављима овог рада.

\section{1. Елизабетанска публика и проблем зеленаштва у Енглеској XVI вијека}

Већ сам први чин Млетачког трговиа обилује мноштвом алузија на Свето писмо, које Шајлок користи у одбрану зеленаштва као легалне професије. Наравно, Шајлок није једини који се служи Библијом да би оправдао исправност свог става и поступака. Са подједнаком успјешношћу то чине и његови омражени непријатељи, Антонио и остатак хришћанске свите, који износе сопствене аргументе против зеленаштва на коме је Шајлок стекао богатство. Готово на исти начин као што Шајлок брани праведност своје обвезнице ослањајући се на ријечи Старог завјета, тако се и његови противници, хришћани Венеције, позивају на ријечи Јеванђеља тражећи милосрђе.

Премда се нека теолошки проницљивија и детаљнија библијска дебата по питању јудаизма насупрот хришћанства, тачније, Старог насупрот Новог завјета, не би могла очекивати од просјечне елизабетанске публике тог доба, нити би се дубоко укоријењен презир и страх Елизабетанаца према јевреској популацији могао рационално разумјети, јер је и онај мали број Јевреја који је евентуално и живио у Лондону тог времена, након што је 1290. године краљ Едвард I издао Едикт о протјеривању, између 16000 и 17000 Јевреја из Енглеске и забранио им повратак (Foley/Coates, 2014: 116)3, покрштен и преобраћен у хришћанство (Cardozo, 1925: 330)4, проблем зеленаштва је био добро познат елизабетанској публици, која га је сматрала једним од примарних моралних питања свог времена. Наиме, зеленаштво за њих није био проблем којим су се бавили становници тамо неке удаљене Венеције, већ непосредан проблем који је елизабетанско друштво имало у сопственом дворишту са њиховим, на раскош навикнутим енглеским господством и зеленашима који су им давали новац на зајам уз немилосрдно високе камате. А да би ствар била још гора, за такво нешто нису могли свалити кривицу на Јевреје, јер их у то доба и није било у Енглеској, већ искључиво на похлепне енглеске трговце и нотаре који су веома често, као залог да ће им обвезница бити исплаћена, заплијењивали комплетна имања енглеским

3 Овај закон је остао на снази све до 1656. године, када га је укинуо Оливер Кромвел (Oliver Cromwell), што говори у прилог чињеници да у доба настанка Млетачког трговца Јевреји званично нису ни живјели на простору Енглеске, а камоли да су се бавили зеленаштвом.

4 Потврда чињенице да Јевреји нису били присутни у елизабетанско доба у Енглеској. 
војводама и грофовима који због презадужености нису били у могућности да их исплате. Значајан утицај на негативан став елизабетанске публике према наведеном проблему имали су и бројни трактати који су штампани, затим памфлети који су дијељени вјерницима током недјељних богослужења, као и проповиједи, у којима су се писци памфлета и проповједници позивали на одломке из Светог писма са циљем да се искоријени „покварени гријех зеленаштва”5 (Wilson, 1949: 4) енглеских каматара, иако ни на једном мјесту у Библији бављење овим занимањем није изричито забрањено (Pettet, 1945: 21-22) могућност злоупотребе давања новца у зајам.

Све у свему, иако један просјечан Елизабетанац можда никада није дошао у додир са једним Јеврејином, а камоли са јеврејским зеленашем, он је био врло добро припремљен да, у контексту свога времена, разумије зашто Шајлок користи старозавјетне алузије као оправдање његовом зеленаштву. Наиме, Шајлок користи библијску Причу о Јакову и Лавану (Прва књига Мојсијева, 30, 28-43)7 као оправдање исправности практиковања зеленашке професије и његових скривених намјера према Антонију. Прецизније, Шајлокова интерпретација наведеног одломка је библијски примјер Јаковљевог оправданог лукавства као одговора Лавану за превару којом га је Лаван практично приморао да се ожени његовом старијом кћерком Лијом умјесто Јаковљеве истинске љубави Рахиље (Прва књига Мојсијева, 29, 15-26) ${ }^{8}$. На овај начин, Шајлок призива сјећање публике на неке од одломака и библијских аргумената које је она врло лако могла препознати са недјељних богослужења, а који су евентуално могли довести до морално дискутабилних ставова и мишљења међу вјерницима елизабетанског доба.

У овом свијетлу, могу се посматрати и модели личности Шајлока и Антонија, као утјеловљења̂ поквареног зеленаша и племенитог господина, која су била лако препознатљива у елизабетанском друштву у коме су трактати, памфлети и проповиједи против зеленаштва били готово свакодневница.

\section{3. Добри Антонио и зеленаш Шајлок као библијски антиподи}

Како су се поменути модели личности Шајлока и Антонија посматрали кроз призму Библије, а што се несумњиво рефлектовало и на припаднике огро-

5 Енг. "...foul synne of usurie..."

6 Е. Ч. Петет (Е. С. Pettet) износи ово запажање у есеју Млетачки трговаи и проблем зеленаштва (Тhe Merchant of Venice and the Problem of Usury).

7 У библијској причи о Јакову и Лавану се очигледно налазе елементи старијих паганских празновјерја која су своје мјесто нашла у Старом завјету и била тумачена као знак божјег благослова. Наиме, након што су Јаков и Лаван постигли договор о будућој расподјели јагњади у односу на боју њиховог руна, на основу кога би Лавану припала само бијела, а Јакову шарена и црна јагњад, Лаван је одлучио да Јакову ускрати могућност потенцијалног укрштања оваца различитих боја тако што је синовима предао на чување све овце које нису бијеле боје. Како би доскочио Лавановом лукавству, Јаков прибјегава облику паганског празновјерја према коме су огољени прутови постављени покрај овнова и оваца током парења изазвали ефекат добијања потомства разноврсних боја, а Јакову обезбиједили благослов преимућства у поређењу са Лаваном. У сваком случају, Шајлок користи поменуту библијску параболу са намјером да изнесе тврдњу како је узвратити на лукавство лукавством не само оправдано, већ и знак надмоћне мудрости која му је као припаднику одабраног божијег народа дарована.

8 О једном од вишеструких Лаванових покушаја преваре Јакова било је говора и у претходној фусноти. 
мне већине елизабетанске вјерске заједнице, најбоље можемо илустровати тиме како су се поједини библијски текстови односили према проблему зеленаштва и давања новца на зајам са обавезом камате. Суштину ових библијских текстова чини дихотомни критеријум који процјењује доброг или лошег човјека на основу тога да ли он убире камату на новац који је дао некоме у зајам, или своја средства даје на располагање другоме у невољи без обавезе враћања. Псалам 15 даје одговор на то ко је достојан божијег спасења и ко ће се спасити вјечнога ништавила: „Ко не даје сребра својега на добит, и не прима мита на правога" (Псалми Давидови, 15, 5).. У псалму 112 се чак и наводи да ће онај који буде давао у зајам на потпуно милосрдној основи, онима који су невољи или лошијег материјалног стања, бити благословљен обиљем и богатством (Псалми Давидови, 112, 3-5), што значи да је и сама ријеч зајам која се најчешће употребљавала у негативном контексту у елизабетанској црквеној заједници, могла бити тумачена и позитивно, уколико зајмодавац не би имао личну корист произашлу из чина давања. Давање у зајам без икаквог одређивања временског рока за враћање, као и без грижње савјести и жала за позајмљеним новцем од стране зајмодавца, јесте императив милосрђа описан у Петој књизи Мојсијевој:

Ако буде у тебе који сиромах између браће твоје у ком мјесту твом, у земљи твојој, коју ти даје Господ Бог твој, немој да ти се стврдне срце твоје и да стиснеш руку своју брату својему сиромаху. Него отвори руку своју и позајми му радо колико му год треба у потреби његовој. Чувај се да не буде какво неваљалство у срцу твом и да око твоје не буде зло према брату твојему сиромаху, па да му не даш, а он зато да вапије ка Господу на те, и буде ти гријех. Подај му, и нека не жали срце твоје кад му даш. (Пета књига Мојсијева, 15, 7-10)

Уз помоћ наведеног хришћанског идеала милосрђа према ближњем који Антонио успјева да постигне у односу према Басанију и осталим хришћанима Венеције, мада би се такав облик испољавања љубави према ближњем могао довести у питање у његовом и односу осталих хришћана Венеције према Шајлоку, у Млетачком трговиу нам се открива и једна потпуно супротна слика окрутног човјека који проналази сатисфакцију у наметању бесрамно високих камата зајмопримцима, па чак до те мјере да његова глад за гомилањем материјалног поприма размјере личне осветољубивости према онима који не оправдавају или осуђују његове пословне подухвате, као што то чине Антонио и остали хришћани Венеције. Открива нам се слика безосјећајног Шајлока чију несклоност да покаже самилост описује Антонио следећим ријечима: „Изишли бисте пре на крај ма с чим, суровим не знам како, но што бисте скротили -

9 Сви цитати библијских стихова у даљем раду су преузети из: Библија или Свето Писмо Старога и Новога Завјета (2003). 
а зар грубљег ичег има ? - Јеврејско срце његово!”10 (Млетачки трговаи, IV, 1). ${ }^{11}$ Међутим, уколико се у библијском свјетлу пажљивије посветимо читању млетачког тргови, увидјећемо да припадност Антонија и Шајлока различитим вјерским конфесијама није оно што их априори дефинише добрим или лошим особама. За елизабетанску публику одгајану у духу и ријечи Библије, Антонијева способност да покаже милосрђе и Шајлоково одбијање да покаже самилост су заправо јасни путокази ко је од њих двојице добар или лош, те чији примјер треба слиједити.

\section{4. Антонијево раситништво или великодушност - Шајлокова и хришћанска перцепција}

Иако би лик Антонија, ако не у потпуности, онда бар у великој мјери, требало да утјеловљује новозавјетни архетип доброг човјека склоног милосрђу према ближњима, Шајлок успјева да пронађе перфидан начин да оспори Антонијеву доброту, замјењујући библијски систем вриједности базиран на духовном односу према Богу сопственим системом вриједности базираном на материјалном богатству и способности да се исто сачува и умножи. Општепризнату Антонијеву доброту међу хришћанима Венеције, Шајлок замјењује тек суздржаним признањем да је Антонио доброг (материјалног) стања (Млетачки трговац, I, 3), ${ }^{12}$ што нас наводи да посумњамо како се Шајлок уопште не слаже са хришћанском оцјеном Антонијеве моралне исправности, а камоли да вјерује како је Антонијево „добро стање” резултат божје промисли. Штавише, Шајлоково помињање „доброг стања” којим алудира на Другу посланицу светог апостола Павла Коринћанима, прецизније речено, на одломак из трећег поглавља ове посланице који гласи: „Не да смо врсни од себе помислити што, као од себе, него је наша врсноћа од Бога" (Друга посланища Коринћанима, 3, 5), представља маестралан Шекспиров начин да се иронично поигра са вишезначношћу ријечи sufficient $^{13}$. Према ријечима светог апостола Павла, човјек постаје „достојан милости божје" (sufficient by the grace of God) искључиво путем божје промисли, а никако захваљујући сопственим заслугама. Самим тим, „достојност милости божје" (sufficiency by the grace of God) постаје идеја изван домена људске могућности схватања, јер оно што људима није могуће спознати, Богу јесте. У складу са тим, Шајлок као да жели да упита Басанија и хришћане Венеције ко су они да доносе суд о томе да ли је Антонио „достојан милости божје”, кад је то ионако дио неког вишег божјег плана. Шекспирово поигравање концептом „достојности милости божије” био је генијалан начин да лик Шајлока приближи

10 Сви цитати стихова Млетачког трговца на српском језику у даљем раду су преузети из Живојиновићевог превода који се налази у издању Шекспирових Сабраних дела из 2011. године.

11 Енг. "You may as well do anything so hard,

As seek to soften that, - than which what's harder?

His Jewish heart" (The Merchant of Venice, IV, 1, 78-80). Сви цитати стихова Млетачког трговца на енглеском језику у даљем раду преузети су из The Merchant of Venice (1996 [2005]).

12 Енг. “...he is sufficient” (The Merchant of Venice, I, 3, 15).

13 У наведеном случају могао би се ставити знак једнакости између ријечи sufficient и њеног синонима worthy. 
публици којој је оваква врста теолошких расправа могла бити позната у то вријеме. Надаље, поставља се питање зашто би ико изразио сумњу у позитиван исход Антонијевих трговачких подухвата, уколико истински вјерује да је Антонио „достојан милости божје”. Заправо, Шајлоков злослутни наговјештај губитка Антонијевих средстава, изложених бројним „опасностима од воде, ветрова, хридина” (Млетачки трговаи, I, 3) ${ }^{14}$, представља Шекспиров суптилан начин да покаже публици како Шајлок негира Антонијеву „достојност милости божје”, алудирајући на одломак из једанаестог поглавља Друге посланице светог апостола Павла Коринћанима: „Много пута сам путовао, био сам у страху на водама, у страху од хајдука, у страху од родбине, у страху од незнабожаца, у страху у градовима, у страху у пустињи, у страху на мору, и страху међу лажном браћом" (Друга посланица Коринћанима, 11, 26). Користећи претходно наведене библијске одломке из Друге посланице светог апостола Павла Коринћанима, Шекспир настоји да покаже публици како функционише Шајлоков мржњом задојен ум. Наиме, гледано Шајлоковим очима, Антонио није ближњи у невољи коме је потребна помоћ, већ „незнабожац и лажни брат”, разметљивац који мрзи јеврејски свети народ, па као такав није „достојан милости божје” која би заштитила његова средства од пропасти.

За Шајлока, Антонио постаје отјелотворење расипника из библијске Приче о блудном сину која говори о млађем сину који од оца узима свој дио имања, и пошто све потроши живећи распусно, долази кући кајући се (Јеванђеюе по Луки, $15,11-32)^{15}$. Антонијево позајмљивање новца без обавезе враћања, Шајлок види као расипништво, што потврђује следећим ријечима, алудирајући на претходно поменуту библијску причу:

Ето, и с том сам трговином на штети: банкрот, распикућа, који мучно да ће смети да помоли главе на Риалту; пропалица који је на трг долазио вазда нагиздан; нека припази на своју залогу: он ме је обично називао дерикожом; нека припази на своју залогу; он је обично позајмљивао новац из хришћанске љубави; нека припази на своју меницу. (Млетачки трговаи, III, 1$)^{16}$

14 Енг."...water-thieves and land-thieves...and then there is the peril of waters, winds, and rocks" (The Merchant of Venice, I, 3, 13-15).

15 Прича о блудном сину дочарава колико се Бог радује сваком покајаном грешнику. Наиме, захтјев млађег сина за својим насљедством, док је отац још жив, представља дрскост, готово исто као да жели да му је отац мртав. Међутим, када добије свој дио, он ниже неуспјех за неуспјехом, те завршава радећи понижавајући посао у свињцу, завидећи свињама на њиховој храни. По повратку кући, отац га дочекује са великодушношћу далеко већом но што је имао права очекивати. Насупрот томе, старији син размишља у појмовима „закона, заслуге и награде”, прије него „љубави и милости”, што може представљати свештенике и фарисеје, који критикују Исуса. Очева радост због повратка изгубљеног сина алегоријски представља Божју љубав и неограничену милост Божју.

16 Енг. "There I have another bad match: a bankrupt, a prodigal, who dare scrace show his head on the Rialto; - a beggar that was use'd to come so smug upon the mart; - let him look to his bond;

he was wont to call me usurer; - let him look to his bond: he was wont to lend money for a Christian cur'sy, let him look to his bond!" (The Merchant of Venice, III, 1, 39-44). 
Међутим, позивајући се на Причу о блудном сину, Шајлок свјесно негира њену основну поруку у којој се одражава сама суштина хришћанске љубави која се испољава кроз синергијско дјеловање једне особе која је спремна да призна своје гријехове и покаје се, те друге особе која је спремна да опрости и буде милосрдна. Примјер оваквог синергијског дјеловања можемо илустровати на односу два пријатеља, Басанија и Антонија. Када Басанио покајнички признаје пред Антонијем своју младалачку раскалашност, тражећи финансијску подршку у наумљеном љубавном подухвату, Антонио му на то одговара: „Молим вас, рец'те само шта је то, Басанио мој драги; ако стоји та ствар у кругу части, к'о што вазда стојите ви, по вољи, верујте ми, можете онда кесом мојом, мноме и свим што имам располагати да подмирите своје потребе” (Млетачки трговаи, I, 1)17. Нема сумње да бисмо овакав Антонијев потез, мјерећи га на скали вриједносног система несебичне хришћанске љубави и пријатељства, назвали великодушним, али би таква оцјена била дијаметрално различита за Шајлока коме је чување и гомилање новца на самом врху његових животних приоритета и који би овај Антонијев потез окарактерисао као расипништво.

\section{5. Шајлокова и Антонијева поимања пријатељства тумачена кроз однос Библије према давању новца у зајам}

Мотив пријатељства у Млетачком трговиу се такође може посматрати кроз проблематизовање питања у вези са давањем новца у зајам, са обавезом враћања камате или без ње. Додуше, у претходном поглављу смо показали да давање новца у зајам не мора бити нужно лош чин уколико представља израз безусловне љубави између два пријатеља који припадају истом народу и вјероисповијести, Басанија и Антонија. Чак и Шајлок сматра да неће бити никаквих потешкоћа у томе да му његов земљак Тубал прискочи у помоћ и позајми новац када каже: „Уцело не бих могао сад одмах три тисуће цекина да наравнам. Ал' шта је с тим? Прискочиће за тол'ко мој рођак Тубал, богат Јеврејин" (Млетачки трговаи, I, 3) ${ }^{18}$, што нам на неки начин открива да се узимање новца у зајам са обавезом враћања од стране зајмопримца и наплаћивање камате од стране зајмодавца није практиковало ни између припадника јеврејске религијске заједнице.

Али шта се дешава са овом праксом међу припадницима различитих вјерских конфесија, у овом случају између хришћана и Јевреја? Да ли зеленашење којим се бави Шајлок оставља мјеста за узајамно пријатељство са

17 Енг. "I pray you, good Bassanio, let me know it;

And if it stand, as yourself still do,

Within the eye of honour, be assured

My purse, my person, my extremest means,

Lie all unlockt to your occasions" (The Merchant of Venice, I, 1, 135-139).

18 Енг. "I cannot instantly raise up the gross

of full three thousand ducats. What of that?

Tubal, a wealthy Hebrew of my tribe,

Will furnish me" (The Merchant of Venice, I, 3, 50-53). 
хришћанима Венеције? Рекло би се да не оставља, јер се и Шајлок и Антонио са презиром односе један према другом. Шајлок осјећа мржњу према Антонију због јавних понижења која трпи од њега ради професије којом је као припадник изопштеног јеврејског племена приморан да се бави (Werblowsky, 1965: 394)19, што потврђује ријечима:

Мрзак је мени што је хришћанин; Мрскији што по глупости простака бадава новац зајми, па нам скида каматњак наш у Млецима; да могу бар једном за врат да му станем ја, заситио бих мржњу своју стару коју спрам њега гајим. Мрзи он наш свети народ, псује тамо баш где трговаца има највише, мене, мој занат, моју законито стечену добит, зеленаштвом то називајући. Нек би племе моје проклето било ако ли му ово опростим икад! (Млетачки трговаи, I, 3$)^{20}$

Ништа мањи презир према Шајлоку као некоме коме су прописане норме Католичке цркве о забрани давања новца у зајам (Werblowsky, 1965: 394)21 стране и туђе не показује ни Антонио, захтијевајући да му Шајлок радије позајми новац као непријатељу и постављајући питање на кога би одговор, бар када су у питању Антонио и остали хришћани Венеције, требао да буде унапријед јасан и недвосмислено одричан: „Јер кад је пријатељство узимало од пријатеља свога камате на јалов метал?"(Млетачки трговаи, I, 3)22

Наглашавањем разлике између позајмљивања новца „својима”, односно пријатељима, и „туђима”, то јест, припадницима других религијских конфесија, у Млетачком трговиу се алудира на укоријењену нетрпељивост између Јевреја и хришћана у овој драми, која има своје библијско утемељење. У Тори, која представља темељ јудаистичког правног и етичког учења, у хришћанској традицији познатијој под називом Петокњижје (првих пет књига Старог завје-

19 У историјском истраживању јудео-хришћанског конфликта по питању зеленаштва, односно каматарења током средњевјековног доба, Вербловски (Werblowsky) наводи да су Јевреји, будући да су практично постали отпадници од хришћанског друштва и његових закона, били приморани да се баве пословима зајмодаваца и каматара.

20 Енг. "I hate him for he is a Christian! But more, for that, in low simplicity, He lends out money gratis, and brings down The rate of usance here with us in Venice. If I can catch him once upon the hip, I will feed that ancient grudge I bear him. He hates our sacred nation; and he rails, Even there where merchants most do congregate, On me, my bargains, and my well-won thrift, Which he calls interest. Cursed be my tribe, If I forgive him" (The Merchant of Venice, I, 3, 36-47).

21 Према наведеном истраживању Вербловског, Католичка црква је у средњем вијеку апсолутно забранила давање новца у зајам међу припадницима хришћанске вјероисповијести.

22 Енг. “...for when did friendship take A breed for barren metal of his friend?" (The Merchant of Venice, I, 3, 133-134). 
та), прави се јасна разлика између позајмљивања новца сународницима и припадницима других народа који не припадају јеврејском народу. Један од истакнутих познавалаца јеврејске културе, рабин Херберт Лоу (Herbert Loewe), тумачи овај двоструки стандард у књизи Рабинска антологија (A Rabbinic Anthology) (Montefiore/Loewe, 1974: 450)23, наводећи да се у Кюизи Левитској изричито забрањује да један Јевреј намеће другом обавезу враћања камате или да евентуално узима добит од њега (Трећа књига Мојсијева, 25, 36-37), док се у Петој књизи Мојсијевој (Поновљени закони) наведена забрана допуњује допуштењем да се каматарење може вршити на онима који нису Јевреји (Пета књига Мојсијева, 23, 19-20). Оваква дословна интерпретација старозавјетних библијских одломака и живот у складу са њима, неминовно је постављала баријеру између Јевреја и хришћана, рефлектујући аспирацију јеврејског народа да се у складу са својом јудаистичком доктрином издигне на пиједестал изнад свих осталих народа од којих су трпили вишевјековна понижења, слично као што Шајлок настоји да преокрене односе моћи између њега и Антонија, стајући му „ногом за врат”.

Нажалост, и поједина хришћанска тумачења претходно поменутог одломка из књиге Поновљених закона су више одмагала, него помагала превазилажењу баријере између Јевреја и хришћана. Епископска Библија (The Holie Bible:conteynyng the Olde Testament and the Newe, 1568), на маргини странице уз овај одломак, даје своје објашњење зашто су се Јевреји тако строго и дословно придржавали заповијести из Торе, односно Петокњижја. Наведени разлог је био тај да су Јевреји у старозавјетно доба били народ тврда срца коме нису били блиски осјећаји самилости и милосрђа према другим народима, те да их није занимало исказивање великодушности према другим народима без остваривања извјесне добити, супротно Христовом новозавјетном учењу. ${ }^{24}$ Овакво тумачење показивало је и традиционалну снисходљивост у складу са којом су се представници англиканске вјерске заједнице понашали према припадницима свих осталих конфесија у Енглеској тог доба, слично као што се Антонио понаша према Шајлоку, држећи му моралне придике о покварености зеленашке професије и оних који се баве њоме.

\section{6. Жеља за доминацијом као разлог антагонизму између Шајлока и} Антонија

Шајлок и Антонио, наизглед двије дијаметрално различите личности, једна оличење покварености, а друга племенитости, ипак показују изненанађујућу сличност када је у питању жеља за доминацијом. И код једног, као и код другог,

23 Херберт Лоу (Herbert Loewe) биљежи своје запажање о томе да је према Кюизи Левитској једном Јевреју забрањено наметати камату (хебр. тарбит) или узимати добит (хебр. марбит) од другог Јевреја. Међутим, иако је једном Јевреју забрањено каматарити (хебр. нешек) другог Јевреја, дозвољено му је наметати камату и узимати добит од једног странца.

24 Енг. "Because they (Jews) were a hard hearted people, therefore was this libertie given them for a time". (Gloss to Deuteronomy, 23, 20). Сви остали цитати из Епископске Библије (The Holie Bible:conteynyng the Olde Testament and the Newe, 1568) у даљем раду су преузети из наведеног оригиналног издања и цитирани само уз реферисање на конкретан коментар библијског одломка поменутог издања. 
ова жеља се манифестује пренаглашеном потребом за самоправичношћу за коју код обојице можемо пронаћи оправдање или, пак, осуду у ријечима Библије.

Први разлог Шајлокове жеље за доминацијом, која првенствено почива на његовом презиру према хришћанима који негирају његову „законито стечену добит”, заснован је на његовој вјери у то да га Бог фаворизује као одабраног потомка светог јеврејског народа. Изговарајући ријечи „наш свети народ” (Млетачки трговац, I, 3) ${ }^{25}$, Шајлок призива испуњење старозавјетног обећања и благослова које је Бог дао А́вра̂му и његовим потомцима. За Шајлока је издвајање А́вра̂ма као „оца многих народа” (Прва књига Мојсијева , 17, 4) знак светости који он као потомак божјег изабраника носи и коме је на тај начин загарантована коначна побједа над Антонијем, мрским потомком старозавјетних јеврејских „непријатеља” (Прва књига Мојсијева, 22, 17). Међутим, Шајлок чврсто вјерује да ће му та побједа доћи од Бога у виду материјалних благодати током његовог овоземаљског живота у Венецији и као последица његовог, бар како га он види, „поштеног” зеленашког занимања. Његова вјера у коначну побједу и доминацију над Антонијем садржана је у одломку књиге Поновљених закона који говори о предуслову за доминацију над другим народима, народима невјерницима. Наиме, овај предуслов се односи на давање зајма другим народима и уздржавање од позајмљивања новца од припадника других народа (Пета књига Мојсијева, 15, 6). Будући да се придржава овог предуслова, Шајлок сматра и очекује да за то треба да буде и адекватно награђен материјалним благодатима и испуњењем услова обвезнице којом држи Антонија у шаци.

Други разлог Шајлокове жеље за доминацијом, као и одговор на питање зашто Шајлок осјећа тако велику дозу мржње према хришћанима, лежи у његовом дубоко укоријењеном страху да ће, попут његових предака из доба римске окупације Израела којима су цариници наметали три пута веће порезе него у осталим римским провинцијама (Hastings, 1963: 824) ${ }^{26}$, бити ускраћен за добар дио његове „поштено” стечене добити. Поредећи Антонија са „пузавим цариником" (Млетачки трговаи, I, 3)27, Шајлок оживљава сјећање на издајнике међу јеврејским народом, омражене сакупљаче пореза који су се на тај начин додворавали римским властима. Када Шајлок описује Антонија као „пузавог цариника”, он показује своје подозрење према човјеку који је некада пљувао његов „јеврејски кафтан” и коме је „сада потребна његова помоћ”. (Млетачки трговаи, I, 3)28 Осим тога, Шајлок користи израз „пузави цариник” као алузију на библијску Причу о фарисеју и иаринику (Јеванђеюе по Луки, 18, 10-14) ${ }^{29}$ са

25 Енг. “...our sacred nation” (The Merchant of Venice, I, 3, 42)

26 У Библијском рјечнику (Dictionary of the Bible) наводи се да је на просторима цјелокупне азијске провинције Римског царства, у чијем је саставу био и Израел, наметнути порез био три пута већи него у осталим провинцијама.

27 Енг. "How like a fawning publican he looks!" (The Merchant of Venice, I, 3, 35)

28 Енг. "You ... spit on my Jewish gaberdine,

And ... it now appears you need my help" (The Merchant of Venice, I, 3, 112-114)

29 Прича о фарисеју и царинику која приказује фарисејског свештеника, разметљивог својим врлина, наспрам сакупљача пореза који понизно моли Бога за милост потребно је ставити у контекст времена у коме је 
намјером да обесмисли њену праву поруку која се састоји у томе да је Богу угоднија покајничка понизност, него претјерана ревност (Hamlin, 2013: 104) ${ }^{30}$, и са циљем да прикаже како је Антонијева понизност само привидна и да се иза ње крије његова подмуклост.

Међутим, Антонијев однос према Шајлоку је све само не понизан. Обраћајући се више Басанију, у име кога је дошао да тражи зајам, него Шајлоку од кога је дошао да тражи зајам, Антонио наступа са непоштовањем и ниподаштавањем према Шајлоку, па га чак и вријеђа: „Басанио, је л’ видиш како се ђаво на Јеванђеље позива кад му треба? Зао створ, кад сведочанства призива, личи на хуљу насмејана лица, на споља леп, а црвљив плод. О, како љуштуру лепу има притворништво!" (Млетачки трговац, I, 3) 31 Иако је, реално гледано, језичак на ваги моћи претегнуо на Шајлокову страну у тренутку када је Антонио дошао да тражи зајам од њега, што је нагнало Шајлока да назове Антонија „пузавим”, Антонио се дефинитивно не понаша у складу са тим описом, јер у односу према Шајлоку показује свој господски понос неспреман да подилази икоме (Brown, 2005: 23)32. Наиме, овај господски понос се у Антонију само додатно распламсао при сусрету са Шајлоком, показавши да се Антонијево унутрашње биће жестоко противи преокрету у односима моћи између њега и Шајлока. Антонијево устрајавање на томе да односи моћи између њега и Шајлока остану непромијењени, додатно добија на интензитету у атмосфери у којој је Антонијев углед међу хришћанима Венеције достигао готово статус обожавања. Ову тврдњу можемо поткријепити парафразирајући Саланијеве ријечи: он каже да за доброг и честитог Антонија нема довољно доброг епитета који би се придружио уз његово име (Млетачки трговаи, III, 1). ${ }^{33}$ Слично томе, на Порцијино питање о томе колико му је Антонио присан пријатељ, Басанио одговара: „Понајприснији,

настала. Током 1. вијека, фарисеји су били познати по строгом поштовању Мојсијевог закона. Фарисеј у овој причи је још ревноснији од осталих фарисеја, пости чешће него што је потребно, даје десетак на све што прими, чак и у случајевима када вјерска правила то не захтијевају. Сигуран у своју исправност, фарисеј не тражи ништа од Бога, па тако и не добија ништа. С друге стране, публикани (јавни службеници који су радили за Рим) су били презрени Јевреји који су сарађивали са Римским царством. Зато што су били најпознатији по прикупљању путарине и пореза они се обично описују као цариници или порезници. Ова прича, међутим, не осуђује њихово занимање, већ поменутог цариника описује као некога ко препознаје своје стање недостојности пред Богом и признаје своју потребу за измирењем. Долазећи Богу у понизности, цариник прима милост и измирење које је тражио.

30 Изнесено стајалиште потврђује и Ханибал Хамлин (Hannibal Hamlin) када говори да су Шајлокове алузије на јеванђеља, у највећем броју случајева, пародијског карактера. Хамлин тврди да Шајлок врло добро познаје, како текст, а тако и поуке јеванђеља, али их намјерно погрешно тумачи.

31 Енг. "Mark you this, Bassanio,

The devil can cite Scripture for his purpose.

An evil soul, producing holy witness,

Is like a villain with a smiling cheek;

A goodly apple rotten at the heart:

0 , what a goodly outside falsehood hath!" (The Merchant of Venice, I, 3, 92-97)

32 Наведену тврдњу поткрепљује општи утисак да Антонио тражи услугу као неко ко је због свог господског статуса ненавикнут да то чини.

33 Енг. “...that the good Antonio, the honest Antonio,

- O that I had a title good enough to keep his name company!" (The Merchant of Venice, III, 1, 12-14) 
а душа од човека, пун врлина, и неуморан предусретљивошћу. Човек у којег стара римска част испољава се кол'ко ни у које душе у целој Италији данас" (Млетачки трговаи, III, 2)34. Оваква претјерана величања Антонијеве личности поткопавају слику о њему као о савршеном примјеру понизног хришћанина, за шта потврду проналазимо у следећим ријечима јеванђеља: „Ви сте они који се градите праведни пред људима; али Бог зна срца ваша; јер што је у људи високо оно је мрзост пред Богом" (Јеванђеље по Луки, 16, 15). Да ствар буде још и гора, Антонијев понос ће се преобразити у надменост у тренутку када поред свих претходно изречених материјалних казни Шајлоку, нареди и Шајлоков прелазак на хришћанство, чиме Антонијева жеља за доминацијом над Шајлоком доживљава своју кулминацију. На овај начин, Антонијев лик постаје много сличнији Шајлоку, приближавајући се више фарисејевом, него цариниковом обрасцу понашања из поменуте библијске Приче о фарисеју и иаринику.

\section{7. Шајлоково богатство: поштено стечено власништво или иметак стечен преваром ?}

Самопроглашени праведници, Шајлок и Антонио, сваки на свој начин кроз библијску визуру проговарају о томе да ли је Шајлоково богатство стечено на поштен или непоштен начин.

Шајлок сматра да је до богатства дошао поштеним путем, угледајући се на примјер Јакова, као старозавјетног претка одабраног јеврејског народа коме Шајлок припада. У том смислу, Шајлоково богатство је само последица благослова којег је он као потомак изабраника божјег Јакова наслиједио, о чему се говори у псалму 146: „Благо ономе којему је помоћник Бог Јаковљев” (Псалми Давидови, 146, 5). Уз то, користећи Јакова као узор, Шајлок потпуно занемарује један „ситни” детаљ који се помиње у Библији у вези са Јаковом. Наиме, Јаков, захваљујући свом лукавству и помоћи мајке Ребеке, преотима брату Исаву право првородства на благослов њиховог оца Исака. По свему судећи, чини се да је овај детаљ апослутно неважан Шајлоку, јер је за њега важније ко посједује благослов, од начина на који је до њега дошао, што имплицира Шајлоково наглашавање ријечи „посједник” (Млетачки трговаи, I, 3) ${ }^{35}$. Оно што нарочито импонује Шајлоку код Јакова је то што Јакова покреће амбиција да потисне расипног Исава, слична амбицији која њега покреће у намјери да својим зеленашким занимањем оствари надмоћ над Антонијем и осталим хришћанима Венеције. Поглавље 25 Кюиге Постаюа нам открива први наговјештај Јаковљеве амбиције који се може видјети у чињеници да је, у тренутку када је рођен, Јаков држао за пету свог брата близанца Исава (Прва књига Мојсијева, 25, 26).

34 Енг. "The dearest friend to me, the kindest man,

The best-condition'd and unwearied spirit

In doing courtesies; and one in whom

The ancient Roman honour more appears

Than any that draws breath in Italy" (The Merchant of Venice, III, 2, 291-295)

35 Енг. "The third possessor; ay, he was the third" (The Merchant of Venice, I, 3, 69) 
Исто поглавље нам даје још један примјер Јаковљеве амбиције и његове спремности да искористи брата Исава, наводећи га да му прода право првородства за јело које је припремио (Прва књига Мојсијева, 29, 33). Нарочито дивљење према Јаковљевој амбицији и лукавству Шајлок показује присјећајући се догађаја из Библије када је Јаков, уз помоћ „његове мудре мати” (Млетачки трговаи, I, 3) ${ }^{36}$, преварио слијепог оца Исака на самртној постељи, тврдећи да је Исав и тако задобио очев благослов (Прва књига Мојсијева, 27, 24-28). Међутим, Шајлоков материјалистички систем вриједности на основу кога он процјењује свијет око себе у овом случају ставља знак једнакости између значења ријечи благослов и благо (богатство). Према истом принципу, Шајлок опонаша библијски архетип лукавог и сналажљивог човјека, утјеловљеног у лику Јакова, који се богати на рачун туђег незнања, као што и он сам гомила своје богатство на рачун наивних, разметљивих и осиромашених госпара, као и свих осталих грађана Венеције који су запали у финансијске проблеме. Штавише, Шајлок је убијеђен да је његово умијеће убирања камате, слично као и Јаковљева вјештина у сточарству, показатељ да је он изабраник божји кога је Бог обдарио даром мудрости, а дарове треба умножавати по узору на библијску Причу о талантима (еванђеље nо Матеју, 25, 14-30; Јеванђеюе по Луки, 19, 12-27). ${ }^{37}$

Антонио се, наравно, супротставља Шајлоковом поређењу са Јаковом, сматрајући га непотпуним и произвољним библијским објашњењем из два разлога. Први разлог је тај да Јаков, за разлику од Шајлока, није самовољно доносио одлуку о томе како ће умножавати божји благослов, већ је у томе „био упућен и вођен руком божјом” (Млетачки трговаи, I, 3) 38. Притом се Антонио у свом тумачењу раније наведене Приче о Јакову и Лавану позива на њено објашњење дато у Епископској Библији (The Holie Bible:conteynyng the Olde Testament and the Newe, 1568) ${ }^{39}$, алудирајући на један други библијски пасус у коме Јаков оправдава начин стицања свог богатства срдитим Лавановим синовима који су кренули у потјеру за њим као чин испуњења божје воље (Прва књига Мојсијева, 31, 9). Други разлог који Антонио износи, оспоравајући Шајлоково поређење са Јаковом, позива се на Аристотелов аргумент према коме је зеленашење противприродан начин стицања богатства ${ }^{40}$ (Аристотел, 1975:

36 Енг. “...his wise mother" (The Merchant of Venice, I, 3, 68)

37 Прича о талантима као Исусова алегоријска прича о господару који одлази на пут повјеривши слугама новац, да би по повратку неке казнио а неке наградио, представља библијску параболу о талентима тумачену као подстицај Исусовим ученицима да користе своје Богом дане дарове („таленте” у свакодневном смислу) у служби Богу, и да преузимају ризик ради Царства Божјег. Неуспјех у коришћењу нечијих талената, како парабола каже, резултоваће осудом. Из овог тумачења је вјероватно и потекло значење ријечи таленат у смислу способности или вјештине.

38 Енг. "But sway'd and fashion'd by the hand of heaven" (The Merchant of Venice, I, 3, 88).

39 Епископска Библија (The Holie Bible:conteynyng the Olde Testament and the Newe, 1568) коментарише Јаковове лажи свом умирућем оцу и преотимање очевог благослова и права првородства од брата Исава на следећи начин: "This subtill dealing of Rebecca and Jacob with Isaac considered by itself blameworthy: but if it be referred to the will of God and the setting foorth of his decree, it is commendable" (Gloss to Genesis, 27, 19).

40 Аристотелов приговор на рачун зеленашења као неприродног начина стицања богатства: „Сасвим је оправдано омражено и зеленаштво, јер се ту добит постиже помоћу самог новиа и новаи, не служи сврси 
17) и који је Англиканска црква у својим проповиједима и памфлетима веома често користила да би осудила зеленашење у елизабетанско доба. Постављајући Шајлоку питање: „Ил' су ваше злато и ваше сребро овнови и овце?” (Млетачки трговаи, I, 3) ${ }^{41}$, Антонио прави разлику између размножавања оваца као природног начина умножавања богатства који се налази у божјим рукама $и$ неприродног начина стицања богатства којим се бави Шајлок, при чему новац рађа још више новца који самом себи постаје сврха, умјесто да се користи искључиво за робно-новчану размјену. Шајлоков одговор на постављено питање: „Не знам да кажем, ал' настојим да се баш тако брзо коте: то утув'те, сињоре мој" (Млетачки трговаи, I, 3) ${ }^{42}$, крије суптилни реторички противаргумент: ко су он и Антонио да преиспитују божју вољу и одлучују о томе шта је природан или неприродан начин стицања богатства? Или, другим ријечима речено: зашто пропитивати Шајлоков начин остваривања добити и стицања богатства, када су они ништа друго до знаци божјег благослова, у крајњој линији, божјег одобравања? Али Антонио не препознаје Шајлоково материјално богатство стечено зеленашењем као показатељ божје мудрости којом је Бог обдарио Шајлока и учинио га својим одабраником, већ као знак Шајлокове духовне и моралне искварености, па га оптужује да изврће ријечи јеванђеља у сопствену корист. Ову оптужбу Антонио износи у виду поређења Шајлока са ђаволом, што представља алузију на одломак из јеванђеља по Матеју у коме се описује друго Христово искушење од стране ђавола који гласи: „Тада одведе га ђаво у свети град и постави га наврх светог храма; па му рече: ако си син Божији, скочи доле, јер у писму стоји да ће анђелима својијем заповиједити за тебе, и узеће те на руке, да гдје не запнеш за камен ногом својом. А Исус рече њему: али и то стоји написано: немој кушати Господа Бога својега" (Јеванђеље по Maтеју, 4, 5-7). Указујући на Шајлока као фалсификатора хришћанског тумачења јеванђеља, Антонио жели да скрене пажњу на то да неко ко је спреман да се користи таквим триковима да би оправдао стечено богатство, засигурно није могао стећи то богатство на поштен начин.

\section{8. Шајлоково инсистирање на употреби облика имена А́врам као по- казатељ неповјерења у божанско провиђење}

Карактеристично за Шајлоково прилагођавање ријечи Библије његовим личним убјеђењима и интересима јесте инсистирање на употреби облика имена А́врам умјесто А́враิм. Разлика између ова два облика истог имена се објашњава у Кюизи Постаюа на следећи начин: „Од мене ево завјет мој с тобом да ћеш бити отац многим народима. Зато се више нећеш звати А́врам него А́вра̂м, јер сам те учинио оцем многих народа" (Прва књига Мојсијева, 17, 4-5). Ова

којој је наменен. Новаи је, наиме, настао ради размене, а камата га умножава па је отуда и добила име, јер деца личе на родитеюе, а камата је новаи рођен од новиа. Стога је од свих начина богаћена овај највише противан природи."

41 Енг. "Or is your gold and silver ewes and rams?" (The Merchant of Venice, I, 3, 90).

42 Исто. Енг. "I cannot tell, I make it breed as fast” (The Merchant of Venice, I, 3, 91). 
промјена имена представља потврду божјег обећања датог А́вра̂му да ће му подарити бројно потомство и учинити га моћнијим од његових непријатеља (Прва књига Мојсијева, 22, 17). Коментаришући ово обећање, Епископска Библија (Тһе Holie Bible:conteynyng the Olde Testament and the Newe, 1568) овдје прави јасну разлику између дарова које Бог пружа људима непољуљане вјере као израз његове безусловне љубави и награда које људима долазе као резултат њихових сопствених заслуга. ${ }^{43}$ Свети апостол Павле у посланици Римљанима напомиње да је испуњење обећања које је Бог дао А́вра̂му потврђено снагом А́вра̂мове вјере у Бога, а не захваљујући његовим личним заслугама (Посланица Римљанима, 4, 12-13).

Међутим, у Млетачком трговиу, Шајлок увијек користи облик имена А́врам ${ }^{44}$ умјесто А́враิм, што показује Шајлоково помањкање вјере у то да је само снага божјег провиђења довољна да се испуни старозавјетно обећање које је Бог дао А́вра̂му, а самим тим и њему као његовом јеврејском потомку, па се због тога окреће ономе што сматра сопственим предностима: лукавству, зеленашкој вјештини и нагомиланој добити. Управо овакав недостатак вјере у божје провиђење додатно доприноси негативној слици коју хришћани Венеције имају о Шајлоку, чиме се све више продубљује јаз њиховог међусобног неповјерења и неразумијевања.

\section{9. Закључак}

Одговор на питање зашто Шекспир користи библијске алузије у Млетачком трговиу да би међу публиком потакнуо расправу о комплексним питањима морала, правде и милосрђа поприлично је јасан. Публици којој се Шекспир обраћа, ријечи Светог писма су одзвањале у подсвијести, као дио свакодневене друштвене стварности на богослужењима. Притом, Шекспир не даје одговоре на поменута сложена питања, већ, дајући глас ликовима Шајлока и хришћана Венеције, износи различите углове гледања на ствари, док публици препушта одлуку о томе чијој ће интерпретацији бити наклоњенија.

Немогућност помирења сукобљених интерпретација по питању зеленаштва: Шајлоковог става према коме је зеленаштво не само легална, већ и праведна професија са библијским утемељењем, и става хришћана Венеције, према коме Шајлок злоупотребљава библијске одломке и давање новца у зајам зарад сопствене користи, показатељ је Шајлокове моралне и духовне искварености. На примјеру односа Антонија и Шајлока према давању новца у зајам, посматраног кроз призму библијских текстова, илустрована су два дијаметрално различита модела личности: једног (Антонија), који у жртвовању за пријатеља види испуњење идеала милосрђа, и другог (Шајлока), који због заслијепљености похлепом и мржњом не показује знаке самилости. Притом

43 Енг. "God giveth his free benefites the name of reward, to provoke men to godliness: not for the merite of the worke." (Gloss to Genesis, 22, 17).

44 Овдје наводимо примјере Шајлокове употребе имена А́врам: енг. “This Jacob from our holy Abram was.” (The Merchant of Venice, I, 3, 67); енг. "O father Abram, what these Christians are!" (The Merchant of Venice, I, 3, 156). 
је мотив „достојности милости божје“ послужио као одличан лакмус папир за приказ како се на љествици Антонијевих и Шајлокових опречних система вриједности посматра давање новца у зајам, а да се за тај чин не тражи никаква надокнада; односно, у конкретном случају, да ли је Антонијева помоћ Басанију израз несебичне љубави и пријатељства или знак Антонијеве непромишљености и расипништва. Антонијева и Шајлокова дијаметрално супротна тумачења библијских алузија по питању односа према давању новца у зајам, са обавезом враћања камате или без ње, рефлектују се на продубљивање нетрпељивости између њих двојице као припадника различитих религијских конфесија. Поред тога, разлози Шајлокове жеље за доминацијом над Антонијем имају коријене у његовој индоктринисаности идејом да је припадник светог јеврејског народа и дубоко укоријењеном страху да ће, по узору на његове претке из доба римске окупације, бити лишен стеченог богатства, док Антонијева жеља за доминацијом почива на устрајавању на томе да односи моћи између њега и Шајлока остану непромијењени, а што се испољава у Антонијевом снисходљивом односу према Шајлоку. Несугласицама између Антонија и Шајлока доприноси и Шајлокова перцепција да је богатство стекао на поштен начин, угледајући се на библијски узор лукавог и сналажљивог човјека, утјеловљеног у лику Јакова, насупрот Антонијевом противаргументу који оповргава Шајлоково поређење са Јаковом, износећи став сродан Аристотеловој тези да је зеленаштво противприродан и, самим тим, непоштен начин стицања богатства. Осим тога, Шајлоково упорно инсистирање на употреби облика имена А́врам умјесто А́вра̂м јесте показатељ помањкања вјере у божје провиђење, што креира додатни раздор између њега и хришћана Венеције.

Као што вајар додаје воду глини да би моделирао скулптуру која ће одољети зубу времена, тако и Шекспир у Млетачком трговиу користи библијске алузије да би обликовао централни драмски конфликт који се огледа у дугогодишњој нетрпељивости између Шајлока и Антонија, учинивши, како ове ликове, тако и комад у цјелини, свевременским. Одржавање овог конфликта представља покретачку снагу којом Шекспир потпуно огољава ликове Шајлока и Антонија, приказујући их у свим њиховим несавршеностима. Захваљујући несавршеностима које се огледају у очигледној немогућности да достигну ултимативни свечовјечански идеал љубави и мира исказан у ријечима: „љубите непријатеље своје” (Јеванђеље по Луки, 6, 35), ликови Шајлока и Антонија су остали веома блиски и нама самима као несавршеним људским бићима све до данашњих дана. Шекспирово мајсторство огледа се и у способности да елементе у драми обавије велом мистерије и да̂ им вишеструка значења. У Млетачком трговиу, Шекспир поставља религиозни и друштвени оквир у коме ликове доводи у стања неразрјешивих унутрашњих противречности, што отвара пут различитим перспективама сагледавања мотива и сукоба интерпретација. 


\section{Литература}

Аристотел. (1975). Политика (Љ. Станојевић-Црепајац, прев.). Београд: БИГЗ. [Aristotel. (1975). Politika (Lj. Stanojević-Crepajac, prev.). Beograd: BIGZ] Brown, J. R. (2005). Shakespeare and his Comedies. London: Routledge.

Cardozo, J. L. (1925). The Contemporary Jew in Elizabethan Drama. Amsterdam: H. J. Paris.

Foley, E., Coates, B. (2014). Shakespeare For Grown-Ups. London: Penguin Random House.

Gee, H., Hardy, W. J. (1914). Documents Illustrative of English Church History. London: Macmillan and Co..

Hamlin, H. (2013). The Bible in Shakespeare. Oxford: Oxford University Press.

Hastings, J. (1963). Dictionary of the Bible. Edinburgh: T. \& T. Clark.

Montefiore, C. G., Loewe, H. M. J. (1974). A Rabbinic Anthology. New York: Schocken Books.

Pettet, E. C. (1945). The Merchant of Venice and the Problem of Usury. In Essays and Studies, 31 (pp. 19-33). Oxford: Clarendon Press.

Pollard, A. F. (1923). The History of England from the accession of Edward VI to the death of Elizabeth (1547-1603). London: Longmans, Green and Co.

Werblowsky, R. J. Z. (1965). The Encyclopedia of the Jewish Religion. New York: Holt, Rinehart and Winston.

Wilson, T. (1949). A Discourse Uppon Usurye. Ann Arbor: University of Michigan.

\section{Извори}

Библија или Свето Писмо Старога и Новога Завјета. (2003). Београд: Југословенско библијско друштво.

[Biblija ili Sveto Pismo Staroga i Novoga Zavjeta. (2003). Beograd: Jugoslovensko biblijsko društvo]

Шекспир, В. (2001). Млетачки трговаи (В. Живојиновић, прев.). У В. Топаловић и Д. Мрђеновић (ур.), Сабрана дела (стр. 320-363). Београд: Завод за уџбенике.

[Šekspir, V. (2001). Mletački trgovac (V. Živojinović, prev.). U V. Topalović i D. Mrđenović (ur.), Sabrana dela (str. 320-363). Beograd: Zavod za udžbenike]

Shakespeare, W. (1996 [2005]). The Merchant of Venice, Second Edition. In S. Wells/G. Taylor, The Complete Works (pp. 2176-2297). Oxford: Clarendon Press.

The Holie Bible:conteynyng the Olde Testament and the Newe. (1568). London: Imprinted by R. Iugge, Printer to the Queene. 


\section{Mladen R. Radulović}

\section{Summary}

\section{DICHOTOMY OF THE CONCEPT OF VALUE IN THE BIBLICAL CONTEXT IN THE MERCHANT OF VENICE}

In this paper, we will address the way in which Shakespeare's biblical allusions in The Merchant of Venice were used in their dramatic context by focusing on biblical allusions as structurally integrated elements of drama. We will try to show how much Shakespeare's knowledge of the Bible acted as a centripetal force in the service of his art and achievement of deeper meaning in The Merchant of Venice, instead of as a centrifugal force focused on deeper meanings outside the drama itself where all roads lead to Rome, more precisely to the allegories of the Holy Scripture. We will try to illustrate how Shakespeare in The Merchant of Venice used many ingenious ways to deepen and expand the effectiveness of characterization, dialogues, indications, ironies with which he elaborated every theme within the play to the tiniest details, adapting it to the biblical knowledge of the Elizabethan audience, whose statutory obligation as subjects of the Supreme Head of the Church of England, Elizabeth I, was to attend worship services every Sunday and on major holidays during the year.

In a narrower sense, this paper aims to explain how certain biblical allusions in The Merchant of Venice perform the function of integral elements of the play and how, through the prism of these elements, many themes and motifs can be viewed as integral and inseparable parts of the play, in our case Shylock's use of the Bible and the motive for lending money. In a broader sense, it should reveal to us how these biblical allusions contribute to the stratification of the play, through which the values inherent in the Elizabethan audience regarding the mentioned theme and motif in The Merchant of Venice are revealed.

\section{Key words:}

The Bible, Christians, Jews, Antonio, Shylock, usury, wealth, love, justice, mercy 